\title{
Legal Education in Nigeria: Problems and Prospects
}

\author{
By J.O. Fabunmi and A.O. Popoola
}

\section{Introduction}

Nigeria attained political independence on October 1, 1960. For her, and indeed the other newly independent states, the attainment of statehood was soon to open new vistas in development and growth. On the legal scene, it is now history that the English legal system was imported into Nigeria as a hand-maiden of Colonialism. Formal legal education of the Western type came in its trail as a direct result of the economic and social policies of the administering power, and was done mainly in the United Kingdom. One of the immediate challenges of independence, therefore, was the setting up of a local machinery for legal education in consonance with the status and demands of Statehood. Nigeria opted for the dual system of legal education whereby a recognised Law degree is required for the admission to the Law School established in 1962. At the Law School, a student takes the necessary examination in addition to other requirements before he can be called to the $\mathrm{B}$ ar.

Nigeria has come a long way since independence. While it is conceded that "we have got to a stage when the necessity to take a stock of the achievements, problems and prospects in this vital area (legal education) of our national life is compelling" 1 , this paper simply aims at calling attention to, and expressing definite ideas on, some important issues of legal education of contemporary relevance. In the process, we cannot help casting glances on, and attempt to appraise, the developments of the past, and chart an outlook for the future.

\section{Historical Perspective}

In discussing legal education in Nigeria, it is fashionable to state that before Nigeria attained political independence in 1960, there was no formal system of legal education locally. 2 If by 'formal legal education' is meant the systematic training and instruction of students in law at the University level with a view to preparing them for admission to the Bar, it would be legitimate to adopt 1960 or thereabout as the commencement year. But if legal education is given the additional meaning for the process of acquiring education in the

1 See, for an instance, E. Nwogogu, A Quarter Century of Legal Education In Nigeria: An Appraisal, (Nigerian Institute of Advanced Legal Studies, Occasional Paper No. 10), p. 1.

2

Ibid. 
science of law which prepares the acquirer of such knowledge for a career in the legal profession; or indeed the knowledge and abilities resulting from such training, then we should look far more behind for our bearing. For as pointed out in another context:

"The Law was a living Law - it was not something detached from the people - it was what they practised, so that law, morals, and religion tended to be very closely related, much more so than in our society" 3

"The law was popular, understood by everybody. There was no special course of instruction given to people to specialize in it. They learnt the Law as they learnt their language during the process of growing up"4

What is stated above is as true of pre-colonial Nigerian societies as it is of the other African societies. Whilst legal education in its present sophisticated form was unknown to these societies, law existed and justice was administered. Dr. Adewoye said much the same thing when he opined:

"Whatever springs from the life and experience of a community and is accepted as binding in regulating inter-personal relations and promoting the well-being of the community, is its Law".5

And so it was the case that the Law grew with the people and the elders and the paramount rulers and their chiefs were deemed to be versed in it.

The point must be made, however, that in the northern part of present-day Nigeria where the Islamic religion flourished, the law, based as it were, on that religion, was mostly written and the economic interactions between the old Empires of the Western Sudan and the Arab had enabled the people from that part to acquire the type of legal education rooted in the Islamic religion6. As the Islamic Law was written, the services of interpreters and professional pleaders versed in the Law were required in the administration of justice. In the Sokoto Caliphate, the alkalai were appointed to administer the Sharia whilst litigents sometimes sought the services of the Mallams to plead for them. Mungo Park was so

3 R.S. Suttner, "Towards Judicial and Legal Integration in South Africa". South African Law Journal. Vol. 85 (1968), p. 438.

4 Ibid.

5 Adewoye, Omoniyi, The Legal Profession In Nigeria 1865 - 1962, Longmans Nigeria Ltd., (1977), p. 4.

6 See H. A. Amankwah et al; "Legal Education In Nigeria Past And Present: A Projection Into The 21st Century" Paper presented at the 24th Annual Conference of Law Teachers, University of Benin, Benin-City. 27th - 30th April 1986, pp. 3-4. 
impressed by the performances of some of these professional pleaders whom he came into contact with among the Malinke that he declared:

'In the forensic qualifications of procrastination and Cavil and the arts of confounding and perplexing a cause, they are not surpassed by the ablest pleaders in Europe'.7

As for the academic profession of Law, itself a component of legal education, the chronicle dates back more than it is often appreciated. To be sure, this arm of the legal profession has been the latest to develop. Yet by the 1920s some notable achievements had been recorded which cannot be skipped in an exercise like this. The credit for these pioneering efforts must, however, go to such colonial officials as Gollan, Sir Percy Girouard, F. H. Ruxton, C. J. Rayner, C. W. Alexander, H.L. Ward-Price and Robert F. Irving, an expatriate Solicitor enrolled at the Supreme Court in $1912^{8}$. Their writings - perhaps not unexpectedly - were mostly on aspects of indigenous land law, and the developments that had taken place in it.

Indeed, it was A.K. Ajisafe, a non-lawyer, who wrote the earliest book by a Nigerian titled Law and Customs of the Yorubas. 9 Before then, and up till the 1930s, only a few Nigerian lawyers had shown some interest in the intellectual side of their profession. Adebesin Folarin, a great patriot and prolific writer, stood out prominently among his colleagues. Apart from his writings on a wide-range of nationalist-oriented subjects, it was him, who founded in December, 1921, the Nigerian Law Journal, with the hope that the joumal "will have the effect more or less of compelling counsel to be alive to his sense of responsibility to his clients ... and arouse him from his sense of lethargy to the domains of legal acuteness and literary culture".10 It was unfortunate that the journal packed up in October 1926. This was due to lack of regular contributions of articles from members of the Bar.

It is thus clear that if legal education is considered in a broad sense, intellectual study of law in Nigeria predated the attainment of political independence and some form of academic activities had in fact flourished in the colonial era.

The distinction for the earliest systematic training and formal instructions in law on the Nigerian soil preparatory to further studies in Britain for call to the Bar must, however, go to the old Department of Law at the Institute of Administration, Zaria which was established to run, among others, the law officers' course, in 1959.

7 Mungo Park, Travels in the Interior Districts of Africa, London (1799), p. 193.

8 See Omoniyi Adewoye, "One Hundred Years of the Legal Profession In Nigeria". Paper presented at the Centenary Celebrations of the Legal Profession in Nigeria, Lagos: 16th - 22nd February 1986.

9 Ibid.

10 Ibid. 
Before then, and for a few years thereafter, Nigerian lawyers had received all their training in the United Kingdom. The minimum qualifications required for practice consisted of a call to the English, Irish or Scottish Bar or qualification as a solicitor in these countries. Thus, every prospective Nigerian lawyer had the same basic legal training as his English counterpart. He either secured admission to one of the English universities or got enrolled at one of the Inns of Court in England. If he opted for the former, he had to, on graduating from the University, pass the final English Bar Examination which is organized by the Counsel of Legal Education in England. With these qualifications, he, on his return to Nigeria, got enrolled at the Supreme Court as a Solicitor and Advocate of the Supreme Court of Nigeria fully entitled to appear in the Superior Courts of record in the land.

This pre-independence dispensation certainly had its defects. Apart from the cost to the families and or the sponsoring bodies, of producing a lawyer in England, the products of this training had little or no exposure to the Nigerian Law. Yet this is the law they were to practise throughout their career.

Besides, the structure of the legal profession in England where they received their training, with its bifurcation into barristers and solicitors and the different programmes of training for each branch, could hardly prepare products of the English legal training enough for practice in Nigeria which from colonial times had had a fused profession. The result was that legal practitioners fully trained in England as either barrister or solicitor were not equipped to take on the function of both arms of the profession.11

This was the state of affairs until 1959 when the Government of the Federation of Nigeria set up a Committee under the Chairmanship of the Attomey-General of the Federation, Unsworth, to consider, among other things, and make recommendations "for the future of the legal profession in Nigeria with particular regard to legal education and admission to practice, the right audience before the courts and the making of reciprocal arrangements in this connection with other countries".

The Committee, in its Report, 12 not only recommended that Nigeria should establish its own system of legal education, it went further to set out the modalities. For instance, it recommended the Faculty of Law, first at the then University College Ibadan, und subsequently, at any other University to be established in future. It also recommended that a Law School to be known as the Nigerian Law School, should be established at Lagos for practical training and examinations in certain subjects; and that a Council of Legal Education should be established.13 It also prescribed that the qualification or admission to legal

11 For further discussion of these defects see $E$. Nwogogu, Op. cit., p. 1.

12 Federal Govemment Printer, Lagos, October, 1959.

13 Unsworth Report, p. 11. 
practice in Nigeria should be a degree in Law of any University in Nigeria whose course for the degree is recognised by the Council of Legal Education, and the course of practical training and examination prescribed by the Council. Any person graduating in Law at a University in Nigeria which has not accepted the syllabus recommended by the Council of Legal Education would be required to take such further examination as the Council may prescribe.

The Report of the Committee was accepted by the Federal Govemment which proceeded to implement it without much delay. Curiously, the authorities of the University of Ibadan did not take concrete steps to implement the recommendation of the Committee that a Law Faculty be established in the University until very recently. The initial talk about a Faculty of Law in the University never really went beyond the discussion stage. Indeed, as early as May 1962, the Principal, K.O. Dike, had announced to the Council that in view of the heavy cut in the Capital Development grants to the University, the Faculty of Law, could not take off unless funds were forthcoming from external sources. 14

It was left to the newer Universities to take up the gauntlet. Thus, in 1961, a College of Law started functioning at the University of Nigeria, Nsukka with courses in general studies preparatory to Law; and in the 1962-63 academic session courses leading to the LL.B. degree began at the Ahmadu Bello University, Zaria and the Universities of Ife and Lagos. These initial developments have been followed in subsequent years by the establishment of a new crop of Federal Universities offering Law degrees. The State Universities in their varieties, a post 1979 phenomenon, have also been left out. The result is that today there are about eighteen Law Faculties in the country with some offering degree courses in the Sharia.

Meanwhile, the Unsworth Committee's recommendation of the establishment of a Law School had been followed up with the setting up of a board under the chairmanship of the Chief Justice of the Federation, Sir Adetokunbo Ademola, to make arrangements for the School. The Committee's recommendation was given Statutory effect with the enactment of the Legal Education Act 196215 under which the Nigerian Law School was established. The School has been waxing strong.

So much for the history of Legal Education. Enough has been written to put issues in their correct perspective. One thing that should be obvious from the discussion so far is that the

14 See $R$ A. Adeleye, "The Independent University, 1962-68" in JF. Ade Ajaye \& Tekena N. Tamuno, The University of Ibadan 1948-73: A History of the first twenty years, (lbadan University Press, 1973), pp. 78-79.

15 Legal Education Act 1962 No. 12. 
English Legal System was imported into Nigeria as a hand-maiden of colonialism. ${ }^{16}$ The establishment of colonial rule gave rise to a highly formalised and sophisticated legal system, which ever since has permeated the entire gamut of our national life. Legal Education came in its trail as a direct result of the economic and social policies of the colonial era and the subsequent change in the political and economic structure made the introduction of a legal system that would be suitable for the new economic and political structure imperative. For these reasons, the English Legal Education was imported and it has since been with us. $17 \mathrm{We}$ will now examine the present framework of legal education in Nigeria.

\section{The Framework of Legal Education in Nigeria}

Legal education in Nigeria now consists of University education and training in the Nigerian Law School. Control of University Legal Education is vested mainly in the University authorities subject to lawful directions from the National Universities Commission, a body which has the responsibility, in consultation with other bodies, for approving courses of instruction in the first instance. 18

The Council of Legal Education also exert in a way indirect control since it has the power to reject the law degree of a University as a basic qualification for admission to the Law School. It is the practice for the officials of the Law School to inspect new law faculties which have applied for approval. Beyond this, the Senate and other relevant authorities of the Universities have the responsibility for the control of studies in their Universities.

At the level of the Law School, which is the second phase of legal education, control is vested in the council of Legal Education. The programme there aims at providing for practical training in the work of a barrister and of a solicitor. The main subjects are therefore concerned with practice and procedure and the preparation of legal documents, all to the end that the student acquires the necessary skills required in practice.

In response to the views expressed by the Body of Benchers and in the wake of mounting disquiet about the standard of legal education, the Council of Legal Education in 1985 set up an Accreditation Panel to inspect the human and material resources of all Faculties of Law at regular intervals in order to ensure that they are sufficiently well-equipped to produce Law graduates of the standard set by the council. There can be no rational dissent

16 For further discussion on this see Adewoye, Omoniyi, The Legal Profession In Nigeria 1865 1962, Op. Cit. p. 14.

17 See also J.O. Fabunmi and Christos Theodoropoulos, "The Reform of Curriculum: Towards Functional Legal Education", paper delivered at the 18th Annual Conference of the Nigerian Association of Law Teachers, Nigerian Law School, Lagos: 26th - 29th March 1980.

18 See the National Universities Commission Act 1974, No. 1. 
on the need for an Accreditation System. ${ }^{19}$ What is not clear is the body which should be charged with the responsibility; the aim of the exercise and the modalities of operation. While a detailed proposal is not being ventured here, 20 it seems that at the least such Accreditation or Visitation Panel or Committee as is charged with the function should consist of representatives of the Bar, the Bench and the Academic branch of the profession. The panel or Committee should also be empowered to inspect both new and old law faculties in order to ensure that standards are maintained in the latter.

\section{The Objectives of Legal Education}

It is of immediate relevance that neither the Unsworth Committee nor the Sir Adetokunbo Ademola Board addressed in specific terms the issue of the objectives of legal education in Nigeria and how to achieve them. The two bodies seemed to be concerned with how Nigeria should establish its own system of legal education and the institutional framework necessary for this. The Legal Education Act of 1962 was also silent on the matter.

It was thus left to the various Law Faculties to adopt and define in varying terms their objectives of teaching Law. The objectives of the Ife programme are quite instructive:

"The aim of the teaching in the Faculty is to present law to students as it exists in Nigeria. Emphasis is accordingly laid on Nigerian statutes and case Law for while Nigerian Law is based broadly on the English Law, the two are not quite the same [...] The courses leading to the degree of Bachelor of Laws are designed both for those who after graduation will proceed to the Nigerian Law School in Lagos and qualify as legal practitioners in Nigeria and for those who wish to obtain the degree as a qualification for employment in international and national agencies, federal, state and local governments, public and other statutory corporations and commercial industrial and other enterprises." 21

The objectives of the University of Lagos programme are more explicit. They are to provide

19 See $E$. Nwogogu, op. cit., pp. 13-15.

20 For a detailed and very interesting discussion of the objectives of legal education in Nigeria, see $A$. $O$. Ilumoka, "Beyond The Law School - Attaining Fully The Objectives of Legal Education In Nigeria", paper presented at the 24th Annual Conference of the Nigerian Association of Law Teachers, University of Benin, 27th-30th April 1986.

21 See University of Ife, Faculty of Law Handbook 1984-86 (African Press Limited), pp. 10-11. 
"a sound University education in Law [...] to satisfy the needs of varied classes of candidates [...] prospective legal practitioners [...] and prospective administrators whose services would be needed in the public service and generally in industrial and commercial establishments. To provide students with a solid foundation of legal knowledge taking into consideration the need to teach law in the light of social, political [...] changes in the society and to inculcate in the student the idea of understanding law not for its own sake but by reference to its relevance to society [...]"22

The University of Jos programme is positive that the objectives of legal education are "not only to prepare a person for membership of the legal profession, giving him technical skills or legal formulae, but to seek to understand human nature, the functioning of society and the application, efficacy and relevance of Law"23

It seems clear form the foregoing that at a general level, the ultimate objective of legal education in Nigeria is to produce a competent lawyer who on qualifying is able to engage in any one of the career options opened to a lawyer in Nigeria. The emphasis in training, therefore, seems to be on Law conceived as fixed rules, principles and procedures. This is done in the Universities where the professional is first initiated into the "mysteries" of law. Here, the emphasis as reflected in the set objectives of the various faculties is to impart knowledge about law in the terms stated above. The orientation is, therefore, unmistakably towards the "Rules". Some non-legal courses are, however, taken along, presumably to further equip the students with a knowledge of the society and the role of law there.24

Apparently, the system of legal education in Nigeria also has implicit in it some objectives clearly based on a pre-conceived idea of the role of a lawyer in society. It is a different thing, deserving further attention, whether this perception of the role of the lawyer in society is accurate and, if not, whether a re-definition of the objectives is not in fact overdue. In this connection, it is good that we constantly bear in mind the overall objective of general education in Nigeria which is to effect national development. The conclusions and recommendations of the National Conference on Curriculum Development sponsored by the Nigeria Education Research Council in 1969 are quite opposite here. The Conference recommended the following as the goals of education "appropriate to the present needs of the society":

(i) The inculcation of the right type of values and attitudes for the survival of the individual and society;

22 University of Lagos, Faculty of Law Prospectus, 1977-80, pp. 2-3.

23 University of Jos, Faculty of Law Prospectus, 1985/86, p. 1.

24 See also A. O. Ilumoka, op. cit. 
(ii) The training of the mind in building valuable concepts, generalisations and understanding of the world around us;

(iii) the acquisition of appropriate skills, abilities and competence, both mental and physical as equipment for the individual to live in his society; and

(iv) the acquisition of a relevant and balanced knowledge of facts about local and world phenomena.

It is significant that these objectives were endorsed with minor modifications in the National Policy on Education 1977, which further states that higher education should aim at, among other things, "the acquisition of both physical and intellectual skills which will enable individuals to develop into useful members of the community". 25 That being the case, perhaps the overall objective of legal education in Nigeria should be to produce a lawyer who in accordance with the national policy on education has acquired appropriate skills, abilities and competence both physical and intellectual to equip him to play his role as a useful member of the community. The remaining part of the paper is devoted to a consideration of the structures for achieving this aim and how adequate these are for the realisation of the set objective.

\section{The Admission Requirements}

The issue of admission requirements into our Law Faculties has generated a plethora of ideas in recent times. For now, the minimum admission requirements into the LL.B degree course in Civil Law are fairly uniform. Universities which admit only direct entry candidates insist on a minimum requirement of an Ordinary Level pass in English and passes at the Ordinary Level and at the Advanced Level in a specified number of subjects or a Diploma in Law obtained from a recognized institution. Candidates with first degrees in some other discipline, the National Certificate of Education, Part II ACCA, ACIS and such - like professional qualifications are also given consideration in some other universities.

As for the LL.B. degree in Sharia the Universities which offer the course insist on Ordinary Level passes in at least five subjects including Arabic or Islamic Religious Studies and two Advanced Level passes or a Diploma in Law. The minimum requirements for the LL.B. degree course in Universities with facilities for the one-year preliminary course is the General Certificate of Education (Ordinary Level) in five subjects including English Language passed at not more than two sittings. It is hoped that when the newly-introduced

25 See Federal Republic of Nigeria National Policy on Education (Federal Ministry of Information, Lagos, 1977), p. 3. 
6-3-3-4 system of education fully takes off the admission requirements will be harmonised, especially now that steps ar being taken to phase out the courses for GCE Advanced Level and Higher School Certificate.

Meanwhile, arguments have continued to range on the need or otherwise to make the LL.B. programme a second degree as obtained in the United States. The call for the possession of a first degree of equivalent professional qualification in some other discipline as the minimum requirement for admission for a first degree in Law certainly has its attractions. The assumption is that if we are really serious about achieving the ultimate objective of producing that notional competent lawyer who has acquired appropriate skills, abilities and competence both physical and intellectual to equip him to play his role as a useful member of the community, a prior exposure to some other relevant discipline up to a first degree level is a sine qua non. There is also much to say for the maturity which a first degree in some other discipline before reading law is capable of giving a law student. More importantly, is the breadth of vision which can be acquired in the process.

The matter was exhaustively discussed by a meeting of the Committee of Deans and other Representatives of the National Association of Law Teachers held at the University of Benin sometime in February 1986, and it was unanimously agreed to continue with the present requirements. 26 Members were of the opinion that the possession of a first degree had not proved to be an advantage in the study of law in Nigeria. On the contrary the statistics have shown that holders of a first degree generally perform relatively poorly in their studies. It will be difficult, however, and in the absence of reliable statistics, to be categorical about the performance in practice or other facets of professional life of lawyers with first degrees in some other discipline.

Quite apparently, the arguments that a first degree in some other discipline will make for the maturity and breadth of vision needed in later professional life look plausible; yet, having regard to some other factors, it would appear that the time is not ripe for such a change in our system of education in Nigeria. The financial cost to the nation and the parents or guardians of students when set off against the imagined benefits to the profession can hardly justify the experiment. The greater danger is that the resultant increase in the period of training and the cost may discourage many prospective students from aspiring to read law and restrict the study of law to the children of the well-to-do. That is clearly out of tune with the fundamental objective of building an egalitarian society built on equal opportunities for all. It is true that the various Law Faculties have been receiving applications for admission from first degree holders, the blunt truth is that except in the case of

26 See the Minutes of the meeting of Deans and other NALT Representatives set up at the 1985 Jos Conference of NALT and held at the Faculty of Law, University of Benin on the 14th of February 1986. 
candidates with fairly comfortable background, the majority of applicants in this category have had to fend for themselves in order to sustain their studies. The result is that in an attempt to make both ends meet they are hardly in a position to concentrate fully on their programmes. The poor grasp of legal principles in the course of their career in the Universities cannot be offset by the corresponding maturity. For these and some other reasons stated above it seems reasonable that for now the study of law should be open to all with the minimum qualifications presently prescribed by the various Unversities. The question of maturity and breadth of vision which the possession of a first degree in some other discipline will ordinarily afford will be taken care of in the discussions that follow.

\section{The Course Contents}

The curricula of all Law Faculties in Nigeria are very similar. It is not far-fetched to say that this is in part due to the conditions laid down by the Council of Legal Education for the approval of the degrees awarded by Universities. All the Law Faculties offer instructions in the core courses - Constitutional Law, Criminal Law, Law of Torts, Law of Contract, Land Law, Equity and Trusts. The Law of Evidence is soon to join the list.27 Other courses of the curricula of our various Law Faculties are Nigerian Legal System, Jurisprudence and Legal Theory, Family Law and Succession, Law of Insurance and Banking, Commercial Law, Taxation, Labour Law, Petroleum and Energy Law, Public and Private International Law, Law of Business Association and Administrative Law. A few Universities also offer courses in Criminal and Civil Procedure and Islamic Law. With the exception of Nigerian Legal System and Jurisprudence and in some Unversities, Commercial Law, these courses are optional and mainly offered in the final year. The range of choice in the final year in the University of Ilorin is wide and strikingly innovative. Provisions have been made for courses like Intemational Trade and Investment Law, Human Rights, Conveyancing and Drafting Law, Introduction to the Law of International Institutions, in addition to the 'traditional' courses listed above. 28

In addition to the Law courses, as stated earlier, students in virtually all the faculties are also required to take some non-legal courses like English, Philosophy, History, Sociology, Political Science, Economics Psychology and General Studies either in the first year or as they progress in their studies. At the Law School the training is supposed to be practical

27 See Council forLe gal Education Circular Ref. No. NLS/262/Vol. 1/152 dated 16th January 1986 addressed to Deans of Law and Registrars of Nigerian Universities.

28 See $R$. W. James, "The LL.B. Curriculum with Particular Reference to the final year Course Groupings" in The Jurist, Joumal of the Law Students Society, University of Ilorin, Ilorin (Vol. 1S), p. 51. 
and the range of subjects include Legal Drafting and Conveyancing, Civil and Criminal Procedure, and Professional Ethics.

It is apposite to ask ourselves at this juncture whether the present curricula are adequate for the needs of our society and of the profession. It is significant that until recently when some modifications were introduced along some desirable lines the contents of the curriculum were almost entirely based on the English pattern. May be it is only to be expected that as majority of the pioneer faculty members were English-trained it was only natural for them to introduce the system with which they are familiar. Thus, in almost all the Law Faculties, students were and still are required to take twelve Law subjects in their three years of study as it is the case in London University.

It is also relevant to ask whether the training in the Law Faculties is not unduly or excessively "rule-oriented", whether the scope and contents of the courses can really equip the lawyer with the breadth of vision required of him in his later-day professional life; whether there is not a yawning gap between the logically arranged legal norms in the textbooks and the stark reality that surrounds their practical operations; whether the Law Faculties have a share in the responsibility for this gap and whether the duties of the Law Faculties are discharged in teaching the 'pure' Law of the Statute books, or whether they should help the students to relate the Law to its social effects.

Again, these questions engaged the attention of the National Association of Law Teachers in Benin City in April, 1986. The unanimous decision was that students should be given more exposure to the non-legal subjects which have bearing on their understanding of the society like Economics, Philosophy, Psychology, Politics and Sociology and some other relevant subjects in the Social Sciences and Humanities. It is hardly disputable that a strong base in these disciplines is increasingly becoming imperative for a fuller understanding of the problems of society. The various Law Faculties should, therefore, gear their programme towards giving the Law students some acquaintance in these disciplines. By so doing, they would also have taken care of the arguments in support of the call to make law a Second degree. It is, however, a matter which has implications for the length of the LL.B. degree programme. This will receive some attention at the appropriate time.

A variant of the problem under consideration and to which a passing reference has been made earlier on is the need to further broaden the range of optional courses open to final year and post graduate students. Courses like International Humanitarian Law, Environmental Law, Law of the Sea, the Judicial Process, the Alien and the Law, Law and Development do not feature on the curricula of many of the Faculties. The present constraints - shortage of funds and of the right calibre of academic staff - are quite obvious. These can be conveniently accomodated at the level of post-graduate studies where there appears to be a need for more specialisation in the LL.M. programme than we have now. In 
the near future, the emphasis may have to shift from broad field of Law like Administrative Law, Constitutional Law or Company Law to specific themes within these subject areas like Securities or Investment Law, Remedies, Human Rights, and the Judicial Process. This will give better effect to the philosophy of graduate studies.

Still on the subject of curriculum, the position of the Sharia cannot be ignored. As already stated, some Universities are offering, in addition to the LL.B degree programme in Civil Law, an LL.B. degree programme in Sharia. If we may ask: is the time ripe for a single LL.B. degree programme which would draw extensively from the Common Law, the Sharia Law and Customary Law in its variety? The immediate advantage of this is that even the LL.B. degree programme in Civil Law would be better enriched for it. For now, in view of the emotion the issue of religion has generated in recent times and having regard to the strong argument that Islam is deeply entrenched in the part of the Country where these specialized programmes are being offered, we may have no option than to continue with the 'dual system'. It is, however, not out of place to start pondering the desirability of teaching one Nigerian Law with a compulsory minimum content of Islamic Law, Customary Law and the regular Common Law and with provisions for specialisation at elective level for each student in any of these areas. As a first step toward this, the various Universities should embark on an aggressive policy of staff development in these branches of Law. So much for course contents. We now turn to the methods of teaching and examining.

\section{Methods of Teaching and Examining}

The predominant method of teaching in the Law Faculties and the Nigerian Law School is by lectures and tutorials. Students are required to attend a minimum fo two lectures of two hours duration and a tutorial of one hour duration a week spread over the session. In recent times, some lecturers have had to dictate notes to their students due to shortage or nonavailability of suitable textbooks. At the end of the course, in the faculties not operating the course unit system students sit for a three hour paper in each subject of the degree examination. Examinations are conducted at the end of each semester in each course by the faculties operating the course-unit sytem.

After a quarter-of-a-century of legal education at the University level in Nigeria, there is an urgent need to address the suitability of the present method of teaching and of examination if we really desire functional legal education in the Country.

At a comparative level, there is much to say for the case-law method of study invented and introduced into the American Legal Education scene by Christopher C. Langdell in 1870 
when he became a Professor of Law and Dean of Harvard Law School. ${ }^{29}$ The method was vigorously opposed but it has endured as the principal method of Legal instruction in the United States though it has been modified and developped to meet new conditions. Langdell conceived of the Library as the Laboratory of the Law students and the cases were the molecules and atoms which need to be analyzed and fitted together. It was a method for showing the development of doctrine and for leading students to ascertain for themselves the essential principles of the Law and modes of analysis used by judges. 30 This method involves a Socratic dialogue between the teacher and his students. Law students are given some cases to read with a view to emphasizing a legal point. For example to demonstrate the separate and distinct personality of a company, the student may be given twenty or more cases to read and he will be prepared to discuss orally any or all of the cases in class. The aim is to enable the student to develop a technique of thinking that is necessary for analysing, comparing and distinguishing fact situations and the applicable Law. The role of the lecturer is to guide discussion through questions on the cases. Students are also required to prepare a major paper for each course. This is supplemented with seminars. 31

The case study method certainly has its attractions and it seems more suited for the objective of functional legal education. Indeed, the method is designed to fulfil in the United States the Nigerian Law School purpose of Legal education for professional practice. There is something to commend this method of teaching to us in Nigeria especially as it has the potential of making the students to look for the law from the primary sources as distinct from secondary materials like the textbooks. The result is that for a student to succeed at the end of session, he has to work hard continuously through the session. 32

Closely tied to the method of teaching is the method of examining. It is relevant to ask whether the English/Nigeria traditional method of lectures/tutorials with sessional examinations is best suited to the attainment of the ultimate aim of legal education that the American type of "case-study" with course unit system? The advantages of the case-study method have been underlined earlier on. The immediate advantage of the course-unit system is that it makes students work continuously hard throughout the session. His fate is correspondingly not determined by a single examination taken at the end of sesssion. Students are required to take at least two examinations in the session. Added to these are the continuous class work and assignments given to students during the session. On the

29 See Erwin N. Grisworld, Law and Lawyers in the U.S. (Harvard University Press, Cambridge, Massachusetts), 1965, p. 51.

30 Ibid. at p. 52.

31 See Report of the Committee on Legal Education presented to Parliament. London, March 1971. Appendix D para. 121 at p. 174.

32 For further discussion on the Case-Law Method see J. O. Fabunmi and Christos Theodoropoulos, op. cit., p. 44-49. 
other hand, the system of sessional examination has the potential of not encouraging continuous hard work on the part of the student. Yet, his fate is determined by a single examination. The obvious advantages of the course-unit sytem notwithstanding, we are, however, staunchly of the opinion that we should continue with the system of sessional examinations with important modifications. While the philosophy of the course-unit system is sound and suitable for the programmes of some other disciplines, it is structurally not suitable for the LL.B. degree programme. The aim of teaching in our Law Faculties should be to give the students a panoramic view of legal principles and the organic connections they bear to one another. That is not done where the student is examined in a set of topics at one examination and another set of topics in another examination. Legal problems do not present themselves in that form in actual practice. Whatever advantages there might be in the courseunit system are negatived by this potential danger to the goal of functional legal education. If we opt for the system of sessional examinations, the obvious defects in the system as highlighted above may be eliminated by grafting the system of continuous assessment on the present scheme of examination. This is what is being done at the University of Ife. The immediate advantage is that students are now made to work hard continously throughout the session. Correspondingly, their fate at the end of the session is no longer determined by a single examination.

\section{Length of Courses}

Presently, the maximum period of study in the Law Faculties in Nigeria is four years for candidates with the General Certificate of Education at the Ordinary Level or equivalent qualifications. Direct entry candidates are supposed to spend three years except in the University of Nigeria which still insists on the four-year programmes for all its sțudents irrespective of their qualifications. When the 6-3-3-4 system of education fully takes off, the Universities will have to harmonise the period of study to reflect the new structure. The four years prescribed for study at the tertiary level under the new system is the minimum period allowed. That being the case, the Universities may in the light of the requirements of their various courses prescribe different duration for these courses beyond the mandatory four years.

Clearly, the ultimate objection of our legal education cannot be attained within the framework of the present four or three years LL.B. degree programme. There is a compelling need to extend the period of study by one more session. This will be sufficient to cover the proposed expanded programme of the Law Faculties. It will also count for the desired maturity of the students. Academic excellence is one thing, experience of life and knowledge of the problems of the society is another. A lawyer with sound knowledge of legal principles and experience of life is to be preferred to the star of a juvenile. 
However, the proposed extension should not extend to the Law School Programme. It does not appear that whatever defects there are in the programme can be remedied by merely extending the period of study. The present duration of one academic year is sufficient for the training offered by the school. What is required of the school is a restructuring of its training programme with a view to restricting itself to offering practical training only in courses which have direct bearing on legal practice like Civil and Criminal Procedure, Legal Drafting and Conveyancing, Law Office Management and Professional Ethics, forensic aspects of evidence and aspects of company law. More time would then be left for 'Court visits' and attachment to Law Offices.

Besides, the introductory courses presently offered by students with qualifications in Law from non-Nigerian Universities and non-Commonwealth Countries alike may be contracted to selected Universities to relieve the Law School of its present burden and enable it to concentrate on practical training. If these suggestions meet with the acceptance of the appropriate authorities then at the most the Law School course can be extended by three months.

Perhaps this is also the appropriate forum to examine the agitation in certain quarters for a decentralisation of the Law School. The British and American examples are often called in aid. But these examples are hardly apt. The history of legal education in the two jurisdictions is different from ours. In Britain, the Inns of Courts started as private institutions. While in the United States the training of a lawyer starts and is concluded in the Universities' Law Schools. A lawyer is, thereafter, required to register in the State or group of states he indends to practise. In Nigeria we have always had a single Law School. This is the only forum where Law students all over the country meet in the course of their academic and prof essional career. Its existance ensures uniform standards in their professional education. It also exposes them to common tradition and makes for the social interaction necessary for the profession.

The strongest argument in favour of decentralisation is the present difficulties encountered by students in securing suitable residential accomodation and the ubiquitious transport problems in Lagos. The solution to this is not decentralisation or the creation of multicampuses, a variant of the former. The solution is for the Federal Government to provide sufficient funds to the School to enable it provide suitable residential accomodation at reasonable cost to the students. If this is not possible in Lagos then the Law School can be shifted to another location outside it. But let it remain one Law School with one Campus. 


\section{The Law Teachers}

In all the Law Faculties the only qualification for Law teaching is a training in Law. It does not require much straining of the mind to conclude that a Law teacher should be sufficiently qualified. Opinions are, however, divided on whether an acceptable legal training without more is sufficient for a career in Law teaching or whether this should be supplemented with some experience in legal practice, in the public service or the corporations. 33 The problem being addressed here is not peculiar to Law Teaching, as it cuts across disciplines. On this issue of qualifications it cut across disciplines. On this issue of qualifications for Law teaching, one cannot but agree with Professor Twinning that "discussion of qualifications is a very sensitive area (because) afterall most of us have a vested interest in romanticising our education after it is over"34. Yet it would be suicidal to ignore the waming of Sir Eric Ashby against the present attitude of "oversimplification of the problems especially in a nation where there is no central control of academic standards" 35 . the Accreditation/Visitation Panel suggested earlier on may well be a suitable agency for controlling standards in this matter. If the qualifications of Law teachers constitute a potential threat to our vision of a functional legal education, the present shortage of the right-calibre of academic staff is even more of a greater danger. Some Universities are making some efforts to attract and retain this calibre of teachers. Yet they hardly stay long enough to make appreciable input. The alternative of recruting expatriate Law teachers who incidentally now dominate the staff list of some of the newer Faculties is proving less attractive. With the introduction of SFEM and the restriction on the home remittances of expatriate lecturers it is increasingly becoming difficult even to attract and retain these teachers.

However, in principle, it is doubtful whether this category of teachers, handicapped as some of them are, in their grasp of principles of Law with local application and understanding of the problems of the Nigerian Society, can meaningfully contribute to the efforts at producing that competent lawyer with the appropriate skills to equip him for his proper role in the Community: the lawyer of our dream. Unfortunately and having regard to our present national situation it does not appear there is any alternative than to continue with their services.

33 For further discussion on Law teaching, see $J$. O. Anifalaje, "Law Teaching in a Developing Society". The Advocate, Vol. 6 (1978/79), p. 72.

34 William Twinning, Academic Law and Legal Development, Taylor Lectures, 1975 (University of Lagos), p. 57.

35 Sir Eric Ashby, Any Person, Any Study, (New York: McGraw Hill, 1971), p. 31. But the Federal Military Government has enacted a Decree which aims at ensuring minimum standards. See Education (National Minimum Standards and Establishment of Institutions), Decree 1985. 


\section{Library Facilities}

If the ultimate objective of our legal education - the creation of a competent lawyer - is to be attained, the establishment of well-equipped and up-to-date Law libraries in the various Universities cannot be overstressed. But it is an open secret that the Universities have not been spared their share of the excruciating pains of the prevailing financial squeeze in the country. Its spill-over effect on library development is already biting hard. But we cannot sit by and allow standards to go down the drain as a cost-saving device. In the circumstance of the evolving culture of self-help, the Universities may be left with no option than to resort to launching libraries' development funds. The University of Morin has already blazen a worthy trail in this direction. Others should not fight shy of following suit. Senior members of the Bar and of the Bench and the established Foundations may in addition be encouraged to donate books to the Law Libraries, as a way of immortalising their names by leaving enduring legacies to posterity.

The establishment of well equipped libraries will save students who cannot afford them the ordeal of passing through the Universities without access to the recommended texts. It will also facilitate the case-study method of teaching discussed earlier on. It would then be easier for the Law Faculties to inculcate in their students the habit of consulting legal materials at the source.

\section{Continuing Legal Education}

The subject of continuing legal education 36 , is an aspect of legal education which has direct bearing on our vocation as lawyers whether on the bench, in active practise, in the classroom or other facets of life. But it is also a dimension that has not been receiving the desired attention. Yet it is trite learning that except a lawyer refreshes his knowledge from time to time after qualifying he stands the risk of relapsing into ignorance.

As for the academic branch of the profession, continuing education is mandatory for the law educators in the sense that they have to research and publish or "be damned" as the popular saying goes. In spite of this, they too can still benefit from lessons at periodic intervals in the art of communication from trained teachers and communicators.

36 For further discussions on the subject of continuing legal education see Jadesola $O$. Akande, "Continuing Legal Education as a Necessary Process for Assessing the Relevance of Law in Society". Paper presented at the Nigerian Bar Association Law Week, February 18th - 22nd 1985. See also $E$. Nwogogu, op. cit.,pp. 21-22. 
The need for legal practitioners in active practice to engage in continuing education is even more pressing. In our complex society of today, it is difficult for legal practitioners to keep abreast of changes in the society and development in the law. Law Reports are published on an irregular basis. Several interesting judgements pass unreported. The few Law Reports are not even within the financial reach of many lawyers. And some of those that can afford them are "too busy to consult them". Yet changes in the profession cut across the entire field. The problem is how to keep the lawyer abreast of these changes. It would appear that the most realistic solution in the present circumstances is to be conducting Seminars and Symposia on selected legal subjects at regular intervals. It is true that many legal practitioners may be "too busy" to attend these discussion groups. This does not detract from their efficacy as means of learning about changes on the legal scene. It beloves the Nigerian Bar Association to mount a campaign of enlightenment for members in this regard.

What should now be engaging the attention of the profession is the appropriate medium for conducting these programmes of Seminar. The Nigerian Institute of Advanced Legal Studies has taken a worthy initiative in this connection. For sometime now, the Institute has been conducting series of Advanced courses in Practise and Procedure at regular intervals for private Legal Practitioners, Law Officers, Members of the Lower Bench and Senior Court Registrars.

While this is a commendable effort, it is doubtful whether it is the proper role for an Institute of Advanced Legal Studies to play. The Nigerian Law School and some of the older Universities should seriously consider mounting programmes of continuing legal education in selected areas of substantive and procedural law. If the Nigerian Bar Association cannot directly institute such schemes on an ad hoc basis, the Association should give active support to institutions engaged in the programmes by reinforcing their efforts with adequate publicity and campaign of enlightenment for members.

What is said above on continuing education also applies with equal force to members of the Bench. The truth is that new members of the judiciary are completely left to educate themselves to the job. But it is an open secret that members of the Bench are recruited from anywhere within the profession once the constitutional requirements relating to appointment are met by the prospective appointees. We know as a matter of fact that it is not service in every capacity within the profession that adequately makes a person a suitable material for the Bench. While one is not advocating that recruitment to the Higher Bench should be restricted to the ranks of legal practitioners in active practice only, the assumption that a lawyer with the basic knowledge of legal texts and probably some experience as a barrister should be able to adjust his knowledge and thinking to the requirements of a judicial office should be jettisoned. 37 While some may, others may not. It is, therefore, 
necessary to organise orientation courses for new appointees to the Bench. Similar programmes had been mounted in the past with the Honourable Sir Udo Udoma as the CoOrdinator. There is an urgent need to resuscitate it in the overall interest of the legal profession, the world of adjudication and the society at large.

Refresher courses should also be organised for serving judges to further acquaint them with developments in the Law and in the society. The period of long vacations of the Courts can be utilised for this purpose. This can be supplemented with the Annual Judges' Conference. The various Courts should also intensify the practice of exchanging judgements among themselves. This would take care of the situation where many Courts are unaware of how their colleagues have handled legal issues which may be the same or similar to those before them.

\section{Conclusion}

The Legal Profession has come a long way from the pre-colonial era with its rudimentary and informal system of legal education. Inspite of the progress made so far there are serious lapses that must be remedied as a matter of urgency. Some of these have been highlighted in this paper. The time is now ripe for the necessary changes and charting an outlook for the future.

In conclusion, we would like to express definite opinions on some issues of interest to the future of legal education and of the legal profession in Nigeria not otherwise dealt with in the body of the paper.

The one that has attracted the greatest attention in recent times is the incidence of growing number of lawyers. This phenomenon has evoked apprehension in some quarters. But it appears the apprehension is not borne out by the statistics. The conclusion that there is a glut of lawyers in the Nigerian market seems more impressionistic than real. True it is that there are concentrations of lawyers in some urban centres of the Country. But when the number of lawyers on active service is matched against the Country's projected population the picture is dismally poor. The point must be made also that the services of lawyers are not presently fully utilised. If their services are fully utilised the lawyers in active service can hardly cope with the demands of the profession. There are also some other avenues for lawyers in the police force, the prison services, the Immigration Department, the Local Governments, the environmental agencies, the mass media and the teaching profession, which are not adequately explored by lawyers themselves. However, if it is certain that there are too many lawyers in the Country, the solution to the problem is not to shut the door to prospective law students. What the Law Faculties can do is to strive to maintain 
standards so that only suitable materials can pass through them into market. When the market can no longer absorb lawyers, aspirants will look elsewhere.

If the argument of number is also the rationale for the rumoured rationalisation of some Law Faculties then the exercise cannot be justified on that ground. If on the other hand the aim is to raise standards, the correct approach is not to arbitrarily close down some faculties on the basis of age. That approach could be explosive and counter-productive. This is one area where the Accreditation Panel of the Council of Legal Education can be meaningfully used. Some criteria may be given a period of grace within which to do so, failing which the 'hammer' may be applied by not recognizing their degrees for purposes of admission to the Law School.

Still on Legal Education, the time is now ripe to formally institute a forum for Deans of Law to meet to discuss matters of common interest. This is presently being done by the Committee of Deans of Agriculture and of the Deans of Education. A Committee of Deans of Law is also overdue.

On a final note, the legal profession as a whole should start pondering over the desirability or otherwise of professional partnerships. The proliferation of private chambers - many of them unviable - does little credit to the image of the profession. The situation in the United States where large professional partnerships loom large should be a beacon of light to us in Nigeria.

The immediate advantage is that scarce human and material resources can be pooled together. This will enhance the quality of practice and the capacity to employ the younger ones. It is also of strategic value as it strengthens the position of the profession which is otherwise sustained by a regime of atomised practice. Besides, it provides the much desired opportunity for improved relationship between the senior and junior members of the profession. The present state of the relationship is not encouraging. The senior members should see the junior ones as colleagues and comrades-in-arms and not as expendable cannot fodder as the young lawyers are often treated. The young ones too should be patient and ready to serve and learn.

The cooperation being sought above should also extend to the Universities. The 'Town' and 'Gown' need to meet from time to time. The academic lawyers can no longer afford to operate exclusively in the 'Ivory towers' in as much as their colleagues in active legal practice cannot afford to treat the academics with suspicion; sometimes with lack of warmth.

We have attempted to highlight the problems facing legal education in Nigeria as well as its prospects. In the training of lawyers at the University and Law School levels, it is clear 
from our analysis that there is room for improvement in terms of the courses offered and the contents of such courses. It is noteworthy that efforts are being made in this regard. The Council of Legal Education has set up a Committee to look into courses offered offered in the Law School and make recommendations to the Council having regard to the need for practical orientation of the courses offered at the Law School. It is hoped that at the end of the exercise, the Nigerian Law School will offer more practically oriented courses then hitherto. The Law Faculties should also re-examine their courses and method of imparting knowledge with a view to making them relevant to the needs of the Nigerian Society.

The need for continuing education of Judges and Lawyers has been emphasised. Towards this end, it is hereby suggested that an Institute of Judicial Administration be established. One of its functions should be organising courses for Lawyers and Judges. This will enable the judicial personnel to update their knowledge and familiarise themselves with new techniques and approaches.

The demand for legal education has reached an unmanageable level which underscores the importance of the profession and indicates future direction. While this is a welcome development, it poses a serious challenge, that of the ability to cope. Given the existing facilities - staffing, infrastructures and library facilities - a lot needs to be done in order to contain the situation. In this regard Govemment's subvention to Law Faculties and the Nigerian Law School will have to be increased substantially, for when a course is so preeminently popular among candidates seeking admission to Universities, this fact cannot be ignored. 